\title{
Research on Teaching System for Innovative Talent Cultivation in Major of Landscape Architecture
}

\author{
An Baiyi ${ }^{1, a}$, Shen Wei ${ }^{2, b^{*}}$ \\ ${ }^{1}$ College of Horticulture, Jilin Agricultural University, Jilin, China \\ ${ }^{2}$ College of Computer Science and Technology, Beihua University, Jilin, China \\ aswabyswaby@163.com, babyswabysw@163.com
}

Keywords: Innovation, Training scheme, Model, Research, Practice

\begin{abstract}
According to characteristic of major of landscape architecture, an effective teaching system for innovative talent cultivation has been established. A novel classifying cultivation model for the student in major of landscape architecture has been constructed by formulating a scientific and rational personnel training programs and curriculums, strengthening educating ability of clients, enlarging the teachers team, reforming teaching contents and teaching methods and improving practical teaching courses arrangement. The distinctive characteristic of specialty has been formed.
\end{abstract}

\section{Introduction}

Since the $1990 \mathrm{~s}[1][2]$, with the national competitiveness and national innovation ability construction problem is put forward[3], the cultivation of innovative talents has become a focus of the world higher education and teaching reform[4][5]. At present many developed countries of the colleges and universities are actively carry out the cultivation of innovative talents[6][7].

In higher education in the United States dedicated to give students lay a solid foundation for a knowledge of science[8], technology and humanities, at the same time[9], pay attention to cultivate students' ability to find and solve problems creatively. At Harvard University as an example, the former Harvard University President Rudenstine pointed out: "in the process of moving towards a new century, one of the best innovative education is beneficial to people, make people become more thoughtful, more the pursuit of ideal and insight, to become more perfect, more successful people."

Our education mainly from the result of innovation[10], innovation ability and creative thinking, etc. It expounds the innovative talents.Distribute in the ministry of education of the education facing the 21st century revitalization action plan, learning resources, pointed out to the connotation of the innovation talented person can understand through three levels.The first level[11][12], innovation refers to the "pioneering unprecedented thing" activities, the result is a kind of new concepts, new ideas, new theories, can also is a new technology, new theory[13], new products.The second level, creative thinking is produced in the process of innovation and create new and unprecedented results of thinking activity, mainly made up of divergent thinking and focus on two forms of thinking, of which the former is more major;Creative thinking has the fluency, flexibility[14][15], creativity and density of four kinds of quality.The third level, the creation of innovative talents is a very strong ability and get used to the talents of creative thinking[16][17].

In order to adapt to the development of modern science and technology and the needs of the landscape ecological environment construction, facing the 21st century garden major undergraduate course personnel training of basic goals can be summarized as "foundation, wide knowledge[18], high quality and strong ability".Around, to achieve the goal of the basic part of agriculture and forestry universities made many beneficial reform and exploration, gradually realize the talent cultivation from the past emphasis on knowledge of master, into the use of knowledge and ability, attach importance to talented person's personality traits[19], and boldly draw lessons from and absorbing the world advanced education ideas and education concept, to emancipate the mind, bold innovation, the implementation of comprehensive quality education.Therefore, explore the 
innovative personnel educational mode under the new situation in garden, deliver the high quality, qualified senior specialized talents for the society, has become a higher landscape education must face a real problem[20].

According to the botanical garden specialized discipline characteristic and the needs of the development of ecological environment construction[21], the analysis of the existing personnel training mode, on the basis of summarizing and refining, built to meet the needs of economic and social development in the new century garden in professional way to cultivate innovative talents, strive to play the part of demonstration and radiation in jilin province and northeast China[22][23].

\section{The research and practice of innovative talents cultivation model}

Based on analyzing the current situation of garden specialty in local colleges, and professional talent training mode reform of gardens, by taking to strengthen the construction of teaching staff, build a reasonable course system, experiment, practice teaching of the first cycle and off-campus series base practice[24], participation, teachers' scientific research of the second loop measures such as strengthening practical teaching link, constructed to meet the needs of social development of landscape architecture professional innovation personnel training mode, so that the students one's deceased father grind rate[25], the first volunteer acceptance rate, graduates signing rate is rising year by year at a time[26].

In the garden at home and abroad and the related professional personnel training mode and approach on the basis of extensive investigation and in-depth analysis, integration of the curriculum system[27], build the practice system, to form the landscape professional talent training scheme;Created the extracurricular humanistic quality cultivation system and promotion system of autonomous learning, constitutes the unlimited class; In addition, this project will be according to the nature of the courses of garden is divided into different modules, respectively, for the reforms of the teaching contents, methods and means, ensure the implementation of the innovative talents training target garden specialty:

\section{The integration of curriculum system}

1) the new garden professional talent training scheme on the basis of integrated optimization, increase academic frontiers classes;

2) the curriculum teaching outline;

3) the establishment of curriculum system makes the landscape professionals knowledge structure more reasonable and perfect, the social adaptation ability enhancement of graduates.

\section{Build a practical system}

Establishing step progressive practical teaching system[28], course as the main line of "experiment, practice, comprehensive practice and graduation practice" system and professional as the main line of "foundation, professional basis, professional" system, thus in stages, the hierarchical cultivate and improve the beginning ability.

\section{The creation of the humanistic quality cultivation system}

Garden specialty students in addition to actively participate in school lectures and competitions, also set up related to professional students, by inviting celebrities, outside experts lecture on humanistic quality (not less than 10 times per semester) and social organizations of all kinds of competitions, effectively promote the professional improvement of students' humanistic quality.

\section{Promotion system of autonomous learning}

Held various academic activities, promote the student garden experts and scholars at home and abroad to communicate, to motivate autonomous learning interest;Encourage students to apply for the school set up by the college students' innovation fund and credits, guide of autonomous learning;By professor please act as the teacher in charge, must graduate as instructors to provide convenience of autonomous learning extracurricular guidance and help.

Teaching contents, methods and means of reform is conducive to strengthening the consciousness of innovation

1) to the botanical garden specialized courses according to their nature is divided into different modules, each have emphasize particularly on different modules of the course content reform, such 
as the fine arts foundation module, through the introduction of different schools of art to make the students thinking diversity;

2) from the tradition to the modern teaching methods, including case teaching, scene teaching, student-centered participatory teaching and various teaching methods;All garden specialty course of using multimedia teaching, part of the trunk curriculum implements the network teaching;

3) the reform of the assessment method, on the basis of the written test, flexible using multimedia test, physical test and field test, such as form, to strengthen the students' innovation consciousness.

\section{Conclusion}

Since our country's higher education to carry out the innovation education and cultivation of talents, jilin agricultural university landscape teaching team to create innovative curriculum system and teaching mode as the breakthrough point, integrating landscape professional teaching environment and conditions, especially in terms of curriculum building and system building, does a lot of exploration and practice of teaching. The results of series are mainly aimed at jilin agricultural university and jilin province garden garden specialty teaching at present main problems of common, will promote the excellent teaching achievements, and good application results. The implementation of the results of the study, elevate the overall landscape of professional teaching level and quality of personnel training, landscape professional teaching construction of other colleges and universities have a certain exemplary role and significance.

\section{Acknowledgement}

The authors wish to thank the Education Department of Jilin Province [2015](127th) and [2015](182nd),Jilin science and Technology Bureau(201467006),Science and Technology Department of Jilin Province (20150204045NY), Jilin Province Education Science Planning Project (GH14126)、(GH14127) under which the present work was possible.

\section{References}

[1] Lucia Naldi,Mattisa Nordqvist.Entrepreneurial Orientation,Risk Taking,and performance in Family Firms[J].Journal of the family firm institute,2007(l):33-47.

[2] Emest L Boyer. Schlarship Reconsidered: Priorities of the Professoriate. Princeton: The Camegie Foundation for the Advancement of Teaching, 1990.

[3] Wallmark J T, McQueen D H, Sedig K Q. Measurement of output from university research, a case study[J]. Engineering Management, IEEE Transactions, 2008, 3:175-180.

[4] Youtie J , Shapira P. Building an innovation hub: a case study of the transformation of university roles in regional technological and economic development[J]. Research Policy, 2008, 37(8): 1188-1204.

[5] Geenhuizen M V, Soetanto D P. Academic spin-offs at different ages: A case study in search of key obstacles to growth[J]. Technovation, 2009, 29(10):671-681.

[6] Fini R, Grimaldi R, Santoni S, et al. Complements or substitutes? The role of universities and local context in supporting the creation of academic spin-offs[J].Research Policy, 2011, 40(8): 1113-1127.

[7] Information on http://www.people.com.cn/GB/32306/33232/14743200.html

[8] Information on http://www.ox.ac.uk/about/oxford-people/famous-oxonians

[9] Anders Lundstrom,Lois Stevenson. Entrepreneurship Policy:Theory and practice[M].New Mexico,Springer,2005. 
[10] Anders Hoffinann,Hesham M. Gabr. A General Policy Framework for Entrepreneurship[M].Dahlerups Pakhus:FORA,2006,

[11] Anders Lundstrom, Lois Stevenson. Entrepreneurship Policy:Theory and Practice[M].Springer, 2010.

[12] Nabi G, et al. From student to entrepreneur: Towards a model of graduate entrepreneurial career-making[J].Journal of Education and Work, 2010,23(5):389-411.

[13] Nabi G, et al. From student to entrepreneur: Towards a model of graduate entrepreneurial career-making[J].Journal of Education and Work, 2010,23(5):389-411.

[14] Youtie J , Shapira P. Building an innovation hub: a case study of the transformation of university roles in regional technological and economic development[J]. Research Policy, 2008, 37(8): 1188-1204.

[15] Wallmark J T, McQueen D H, Sedig K Q. Measurement of output from university research, a case study[J]. Engineering Management, IEEE Transactions, 2008, 3:175-180.

[16] Emest L Boyer. Schlarship Reconsidered: Priorities of the Professoriate. Princeton: The Camegie Foundation for the Advancement of Teaching, 1990.

[17] Fini R, Grimaldi R, Santoni S, et al. Complements or substitutes? The role of universities and local context in supporting the creation of academic spin-offs[J].Research Policy, 2011, 40(8): 1113-1127.

[18] Information on http://www.people.com.cn/GB/32306/33232/14743200.html

[19] Information on http://www.ox.ac.uk/about/oxford - people/famous - oxonians

[20] Anders Lundstrom, Lois Stevenson. Entrepreneurship Policy:Theory and Practice[M].Springer, 2010.

[21] Lucia Naldi,Mattisa Nordqvist.Entrepreneurial Orientation,Risk Taking,and performance in Family Firms[J].Journal of the family firm institute,2007(l):33-47.

[22] Anders Lundstrom,Lois Stevenson. Entrepreneurship Policy:Theory and practice[M].New Mexico,Springer,2005.

[23] Geenhuizen M V, Soetanto D P. Academic spin-offs at different ages: A case study in search of key obstacles to growth[J]. Technovation, 2009, 29(10):671-681.

[24] Anders Hoffinann, Hesham M. Gabr. A General Policy Framework for Entrepreneurship[M]. Dahlerups Pakhus: FORA, 2006,

[25] Information on http ://www.chinahr.com/news/

[26] Information on http ://www.ntu.edu.tw/chinese

[27] Information on http://www.cyut.edu.tw

[28] Information on http://cpc.people.com.cn/ 